Gut, 1984, 25, 760-783

Progress report

\title{
Macrophage activation, chronic inflammation and gastrointestinal disease
}

The involvement of macrophages in chronic inflammatory conditions has been the subject of considerable experimental investigation in recent years. Macrophages are able to secrete a wide range of biologically active compounds. They are important in the control of infection and, through their immunological and non-immunological receptors, macrophages interact with other cell types and a wide variety of proteins.

Monocyte proliferation is apparent in a number of disorders, including collagen diseases, many infectious diseases, neo-plastic conditions and chronic inflammatory gastrointestinal diseases. ${ }^{1}$ Generalised proliferation of mature macrophages is present in chronic granulomatous conditions such as tuberculosis, brucellosis and other infections by obligate intracellular parasites as well as in berylliosis and sarcoidosis. Other examples of macrophage proliferation include storage diseases - for example, Gaucher's disease, neoplastic macrophage proliferation and monocyte-macrophage dysfunction syndromes. The latter syndromes include chronic granulomatous disease ${ }^{2}$ and various lymphoproliferative disorders. ${ }^{3}$ Macrophage dysfunction may also result from adrenocorticosteroid administration or exposure to ionising radiation. ${ }^{1}$

Macrophage cell function has been extensively investigated in disorders such as lepromatous leprosy, miliary tuberculosis, disseminated fungal infections and in Hodgkin's disease. Intrinsic or acquired functional defects, however, have not been convincingly proved in these conditions. ${ }^{+}$

Recent information on the tissue damaging potential of compounds released from activated macrophages has focused interest on a wide variety of chronic inflammatory conditions where macrophages may potentiate tissue damage in a non-specific manner. ${ }^{5}$ Early work in this area concentrated on rheumatic diseases where the results strongly supported the concept of macrophage protease involvement in the promotion of inflammation. ${ }^{6}$ These ideas have been more recently extended to various alimentary conditions, ${ }^{7-10}$ including acute or chronic liver disease and inflammatory bowel disease.

The purpose of this review is to highlight recent advances concerning macrophage function, kinetics, activation, and heterogeneity and to consider how far macrophages may be involved in the promotion of inflammation in a variety of gastrointestinal diseases. General information will be presented, followed by a detailed review of the literature relevant to alimentary disease.

\section{Macrophages}

ORIGIN AND KINETICS

Monocytes in the blood constitute a mobile pool from which tissue 
macrophages may be derived. The capacity of both monocytes and tissue macrophages to proliferate is limited, and therefore the provision of adequate numbers of macrophages, especially at an inflammatory focus is dependent upon delivery of blood monocytes. Circulating blood monocytes are derived from a rapidly proliferating precursor pool of cells in the bone marrow, termed promonocytes. The same basic stem cell may give rise to either monocytes or granulocytes and differentiation is controlled by specific colony stimulating factors derived from monocytes, lymphocytes or endothelial cells. ${ }^{11}$

Under normal conditions, peripheral blood monocytes circulate for 24-100 hours and randomly migrate into the tissues. ${ }^{12}{ }^{13}$ When tissue macrophages are removed from the body and reinjected, they tend to localise in their original sites - for example, Kupffer cells localise to the liver. ${ }^{14}$ The factors influencing monocyte localisation in any particular tissue, however, is poorly understood. The question of how peripheral macrophage populations are replaced under steady state conditions is not conclusively settled. ${ }^{15}$ Studies concerning the origin of liver macrophages in the mouse have indicated that about half of all blood monocytes eventually become Kupffer cells and that the turnover time of Kupffer cells is 21 days. ${ }^{16}$ The current consensus ${ }^{17}$ is that both in the normal steady state and in inflammatory situations macrophages present in the tissues are largely derived from blood monocytes. A small and variable proportion may arise from local proliferation, especially during acute inflammation. ${ }^{15} 1819$

Three changes in monocyte kinetics have been observed during inflammation. ${ }^{20}$ Firstly, premature monocytes are released from the bone marrow; secondly, there is a temporary shortening in cell cycle time in the precursor pool and, thirdly, more stem cells appear to be diverted to monocytopoiesis. All these changes result in an increased monocyte pool and presumably increased numbers of derivative cells at the site of inflammation. The magnitude of these changes depends on the inflammatory stimulus and the consumption of macrophages at the site of inflammation. For instance, there are more marked changes in tuberculosis compared with sarcoidosis, which are examples of high and low turnover granulomatous conditions. ${ }^{21}$

\section{MACROPHAGE FUNCTION}

The mononuclear phagocyte system is involved in five major areas: (a) defence against microorganisms, (b) removal of dead or damaged cells, cell debris and inorganic material, (c) regulation of haematopoiesis, (d) cooperative and effector functions in the immune response, (e) synthesis of biologically active compounds such as complement components, prostaglandins, interferon and neutral proteases.

In this review, the secretory functions of the macrophage in relation to activation and inflammation will be considered in detail and other aspects of macrophage function will only be briefly outlined. These other functions of the macrophage may, however, be highly relevant to infections, allergic and autoimmune mechanisms in inflammatory bowel and liver disease, and to the development of immunological abnormalities such as the hyperglobulinaemia of liver disease. ${ }^{22}$ 
DEFENCE AGAINST MICROORGANISMS

Macrophages are the principal cells involved in killing intracellular parasites such as mycobacteria, ${ }^{23}$ toxoplasma $^{24}$ and cryptococci. $^{25}$ Macrophage activation was a term used to describe the enhanced bactericidal properties of macrophages previously exposed to intracellular bacteria. ${ }^{26}$ This term has now adopted a wider meaning.

Apart from activation, macrophages need to exhibit efficient chemotaxis, phagocytosis and intracellular killing in order to eliminate these microorganisms. Monocyte chemotaxis is slow in comparison with neutrophil movement. Mediators of chemotaxis include complement components (C5b), lymphokines and derivatives of phospholipids. ${ }^{27}$ Inhibitors of chemotaxis (interacting with the cells) and inactivators (interacting with the chemical mediators) are present in serum in different disease states. ${ }^{28}{ }^{29}$ Once macrophages arrive at an inflammatory site, they remain there under the influence of a lymphokine, migration inhibition factor which activates the cells and results in increased adherence. This molecule is probably identical to macrophage activating factor.

Cells that have been exposed to a chemoattractant show enhanced expression of surface complement receptors and are thus better able to adhere to opsonised particles. ${ }^{30}$ Subsequent particle ingestion is an energy dependent process involving the activation of actin binding protein, which leads to actin polymerisation to microfilaments. These microfilaments provide the forces for pseudopod formation and particle engulfment. ${ }^{31}$ Particle ingestion depends on the surface receptors involved and the state of activation of the cell.

Macrophages possess multiple mechanisms for killing or degrading ingested organisms. These include the generation of hydrogen peroxide ${ }^{32}$ and other oxygen-derived products. ${ }^{33}$ Myeloperoxidase and other peroxidase activity ${ }^{34}$ have been shown in these cells. Lysosomal fusion with the phagaocytic vacuole suggests that cationic proteins, hydrolases and catalases are also important in bacterial degradation. ${ }^{35} 36$

REMOVAL OF DAMAGED CELLS, DEBRIS AND INORGANIC MATERIAL Changes in erythrocyte surface membranes caused by immunoglobulin coating, physical or chemical injury, surface carbohydrate alterations or aging result in erythrophagocytosis by the mononuclear phagocyte system. ${ }^{37}$ Alveolar macrophages clear particulate matter from inspired air. ${ }^{38}$ Various inorganic materials such as beryllium, barium salts, zirconium and silica are localised within tissues, often within macrophages. This eventually results in granulomatous and excessive fibrotic reactions.

REGULATION OF HAEMATOPOIESIS

The formation of granulocyte and monocyte colonies in culture is dependent on substances with specific colony simulating activity. Circulating monocytes and macrophages are the main source of colony stimulating activity in man. ${ }^{39}$ Granulocytes are able to produce compounds such as lactoferrin, with colony-inhibiting activity. These compounds block the resting but not the activated production of colony stimulating activity by monocytes. ${ }^{40}$ Further control of marrow stem cell proliferation is possibly provided by macrophage production of prostaglandin $E$, which limits stem cell proliferation and is produced in response to raised levels of 
colony stimulating activity. ${ }^{41}$ Macrophages therefore control the proliferation of their own and other progenitor cells through both positive and negative feedback systems. Bone marrow macrophages have been shown recently to influence the growth of early and late committed erythoid precursors through the synthesis of soluble factors. ${ }^{42}$

COOPERATIVE AND EFFECTOR FUNCTIONS IN THE IMMUNE RESPONSE Over the last decade a great deal of experimental work has increased the understanding of these complex and central functional roles of the macrophage. It is beyond the scope of this article to discuss in depth the immunoregulatory role of the macrophage and the reader is referred to a recent review by Unanue. ${ }^{43}$

In summary, mononuclear phagocytes have been shown to exert a fine control on the early events that lead to antigen stimulation of $T$ and $B$ lymphocytes. They regulate the extent to which lymphocytes are stimulated, and respond as effector cells to responses from stimulated lymphocytes. Macrophages are important in early events through their ability to take up antigen, to express Ia (Dr) and to secrete lymphostimulatory molecules. The central role of Ia (Dr) antigen expression and macrophage-T cell interactions is now widely accepted. In late events, macrophages function as effector cells in terms of microbicidal and cytotoxic activity as well as in the modification of lymphocyte responsiveness. Their efficiency in these events depends on the state of activation of the macrophage.

SYNTHESIS OF BIOLOGICALLY ACTIVE COMPOUNDS

There are a wide number of products synthesised and released by macrophages. These can most usefully be divided into various broad categories as indicated in Table $1 .^{44}$ The production of these compounds varies widely in different circumstances and is detailed more specifically in the sections on macrophage activation and on macrophage secretion and its relationship to inflammation.

\section{MACROPHAGE ACTIVATION}

The ability of macrophages to function efficiently depends on their state of activation. The term 'activated macrophage' was introduced by Mackaness $^{26}$ to describe the enhanced bactericidal properties of macrophages previously exposed to intracellular bacteria. In recent years this term has been applied to describe a wide range of functional changes in the macrophage, not necessarily resulting in increased bactericidal activity. In biochemical terms, the secretion of plasminogen activator, a neutral proteinase, seems to correlate well with macrophage activation as originally defined. ${ }^{45}$ The induction of the synthesis and secretion of plasminogen activator may depend on a number of sequential metabolic changes. ${ }^{46}$ The latter may occur earlier than those changes required for full microbicidal activity. At present, therefore, it is best to describe macrophage activation in terms of the function under study, such as bactericidal, tumouricidal. phagocytic, or metabolic activity and in terms of the agent used to induce macrophage activation. ${ }^{47}$

A number of agents are able to activate macrophages, and these are tabulated in Table 2. Possible interactions between these agents and 
Table 1 Secretory products of macrophages*

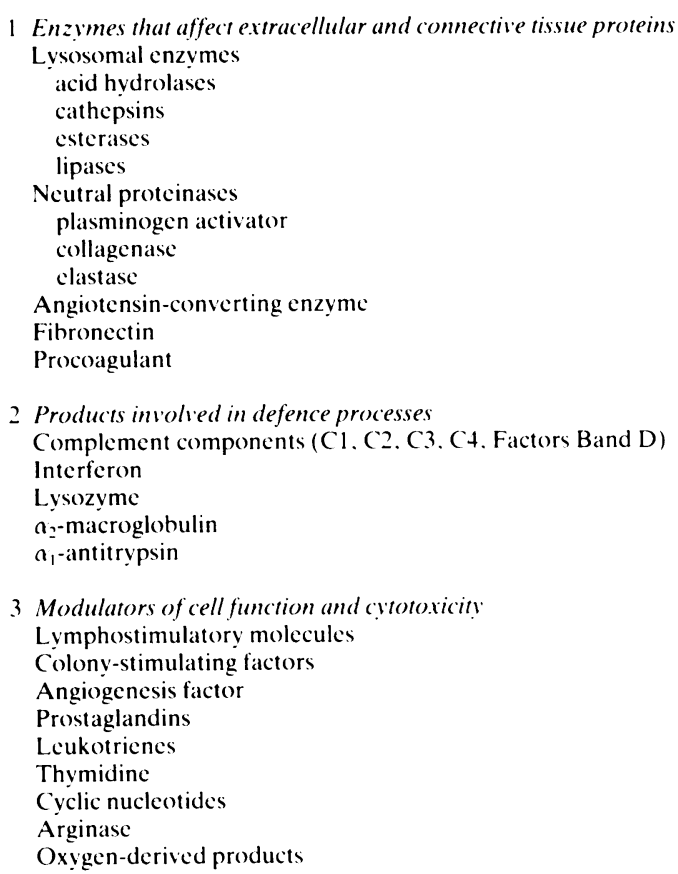

* This table is not intended to be comprehensive. hut covers the major groups of products known to be released by macrophages.

receptors on the macrophage plasma membrane have been recently reviewed. ${ }^{53}$ Alterations in cyclic AMP, cyclic GMP and phosphatidylinositol turnover are related to changes in macrophage activity. Many agents have been used to increase the yield of macrophages from the peritoneal cavity. Cells thus elicited show some of the features of activated macrophages, but not all the biochemical changes associated with fully activated cells are found. ${ }^{54}$ These elicited cells can be fully activated in vitro by agents normally only effective in vivo. ${ }^{55}$ The induction of cytotoxicity for tumour cells ${ }^{55-57}$ and the secretion of plasminogen activator $^{46}$ may require the operation of at least two signals. In vivo, it is probable that macrophages are influenced by more than one group of activating molecules, and once initiated the sequence proceeds in a stepwise manner dependent upon the appropriate activation signals and the presence of responsive precursors. ${ }^{58}$ It has been suggested that this

Table 2 Macrophage activating agents

1 Lvmphokinest大

2 Polyanions (endotoxin. ds-RNA. ${ }^{14}$ glucan)

3 Complement components (especially $\left.C 3_{n}\right)^{511}$

+ Immune complexes ${ }^{51}$

5 Interferon 5 ? 
sequence may provide a protective mechanism restricting the development of changes which might otherwise result in local tissue injury. ${ }^{59} \mathrm{~A}$ hypothetical sequence is shown in Figure 1. After activation, many macrophage properties are altered, and these are briefly tabulated in Table 3.

MACROPHAGE SECRETION AND CHRONIC INFLAMMATION

Macrophages comprise a significant component of any chronic inflammatory infiltrate. These cells modify their pericellular environment and influence the function of other cells within the inflammatory lesion; see Table 1 as a guide to the categories of secretory products.

1 ENZYMES AFFECTING EXTRACELLULAR AND CONNECTIVE TISSUE PROTEINS

Lysosomal enzymes

There are a large number of hydrolytic lysosomal enzymes, which are usually localised as intracellular enzymes within the lysosomes. With maturation and, especially activation the number of cytoplasmic lysosomes and the activity of associated enzymes increases, reflecting increased synthesis. ${ }^{60}$ The amount of enzyme released can vary from a relatively small percentage after a phagocytic challenge in normal cells to extensive release $(80 \%)$ in activated cells. ${ }^{61}$ Selective release has been shown to be initiated by agents that provoke chronic inflammation, ${ }^{61} 62$ such as zymosan, chrysolite asbestos, ${ }^{63}$ antigen-antibody complexes formed at equivalence ${ }^{64}$ and lymphokines. ${ }^{65}$ Such release is selective in nature, the cells retaining full viability as judged by other criteria. Once initiated, active secretion proceeds independently of the intracellular fate of the ingested material. ${ }^{62}$ Alterations in lysosomal enzyme terminal sugar residues and state of phosphorylation during synthesis may well determine their subsequent transport and storage with mannose-6-phosphate intracellular receptors playing a central role. ${ }^{66}$

The activity of these enzymes in the extracellular milieu will depend on $\mathrm{pH}$, the presence of protease inhibitors and the proximity of the cells to the substrate. Acid hydrolases, in particular cathepsins, can degrade collagen, proteoglycan and basement membranes. ${ }^{5}$ Subcutaneous injection of acid hydrolases can produce chronic inflammation. ${ }^{67}$

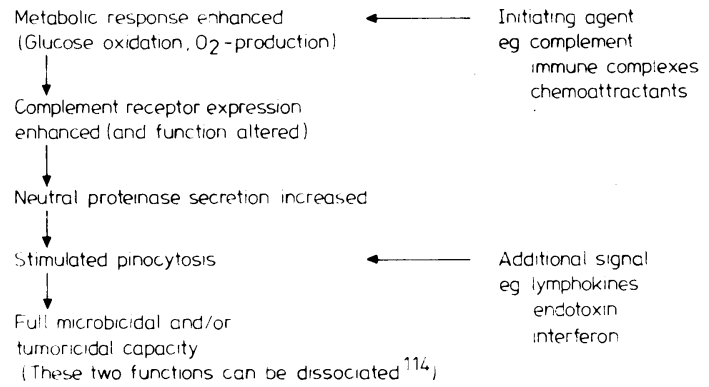

Fig. 1 Schematic representation of macrophage activation sequence. 
Table 3 Some properties of activated macrophages

Morphological

Increased size and adhesiveness

Enhanced spreading, membrane ruffling

Biochemical

Increased glucose oxidation

Enhanced protein synthesis

Secretion of lysosomal enzymes

Increased neutral proteinase production

Surface changes

Increased number of Fc-receptors

Altered function of complement receptor

Decreased expression of lectin-like receptors

Increased responsiveness to chemotactic stimulation

Functional

Enhanced ability to kill intracellular pathogens

Increased cytotoxicity against tumour cells

Adapted from Ogmundsdottir and Weir $;{ }^{53}$ Hopper, Wood, and Nelson. ${ }^{59}$

\section{NEUTRAL PROTEINASES}

These enzymes are synthesised and secreted by macrophages, especially in the activated state. ${ }^{68-70}$ This appears to be a two stage process involving initial macrophage activation, followed by a phagocytic stimulus. ${ }^{46}$ Virtually all the production of these enzymes is for export. Collagenase and elastase are able to degrade their appropriate substrates if the amount released exceeds the local concentration of protease inhibitors. Plasminogen activator may amplify the inflammatory reaction by promoting the generation of coagulation factors, tissue kinins and complement cleavage products as well as by activating collagenase. ${ }^{6}$ There is convincing experimental evidence for the ability of these enzymes, either independently or in conjunction with lysosomal hydrolases, to degrade connective tissue matrices. ${ }^{71} 72$ The deleterious effects observed on connective tissues in chronic inflammation may well follow the release of these enzymes from macrophages.

It is widely accepted that the inability to neutralise liberated leucocyte proteases results in tissue damage in lung, liver or other tissues in individuals with $\alpha_{1}$-antitrypsin deficiency. ${ }^{73}{ }^{74}$ These clinical observations in $\alpha_{1}$-antitrypsin deficiency strongly suggest that the release of these enzymes is relevant to human clinical disease, although there is no proven association with inflammatory bowel disease. ${ }^{75}$

The production of angiotensin converting enzyme ${ }^{76}$ fibronectin $^{77}$ and procoagulant ${ }^{78}$ by macrophages has been shown. The significance of these findings in relation to inflammation remains unclear. Angiotensin converting enzyme production is one of few macrophage secretory products shown to be induced by corticosteroid exposure. ${ }^{76}$

2 PROduCts involved IN DEFENCE PROCESSES

As indicated in Table 1, many complement components are synthesised by macrophages. There is considerable heterogeneity among different macrophage populations in their ability to synthesise these components, 
probably reflecting different states of activation and maturity. ${ }^{79}$ The cleavage product of $\mathrm{C} 3, \mathrm{C} 3 \mathrm{~b}$, is an important molecule in macrophage activation and amplifies the local activation of macrophages at sites of inflammation (Fig. 2).

Macrophages synthesise classical or Type I (wide $\mathrm{pH}$ stability) interferons ${ }^{8081}$ and are essential cooperative cells for the production of Type II (acid labile) interferons by T lymphocytes. ${ }^{82}$

Lysozyme is a major secretory product of both monocytes and macrophages, but the precise role of this enzyme remains uncertain. Synthesis and secretion remain remarkably constant under varying experimental circumstances, ${ }^{83}$ and this is a useful cell-specific marker for mononuclear phagocytes in culture. Polymorphonuclear neutrophils are the only other cells that produce large amounts of lysozyme, which has some bacteriolytic activity. ${ }^{84}$ Recent evidence suggests that it is a potent inhibitor of polymorphonuclear neutrophil chemotaxis and oxidative metabolism and may thus modify the inflammatory response ${ }^{85}$ There is no evidence, however, that lysozyme plays an important role in chronic inflammation.

Mononuclear phagocytes synthesise $\alpha_{2}$-macroglobulin ${ }^{86}$ and $\alpha_{1}$ antitrypsin. ${ }^{87}$ This appears to be more prominent in mature tissue macrophages. These proteins are able to inhibit the activity of plasminogen activator, elastase, collegenase, and lysosomal hydrolases. Simultaneous release of proteases and protease inhibitors, together with phagocytosis of protease-inhibitor complexes, may help to control local protease activity.

\section{MODULATORS OF CELL FUNCTION AND CYTOTOXICITY}

The release of lymphostimulating molecules has been recently reviewed by Unanue. ${ }^{43}$ Colony stimulating factor release has already been mentioned in the context of regulation of haematopoiesis.

Through the release of a factor or factors involved in vascular growth, activated macrophages may mediate microvascular proliferation. ${ }^{88}$

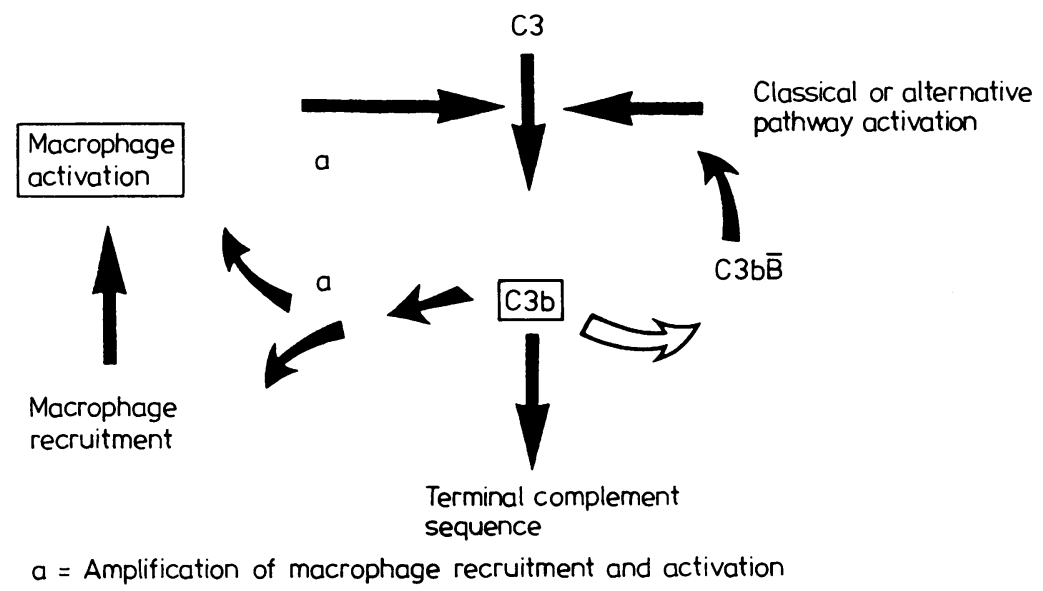

Fig. 2 Complement component (C3b) involvement in macrophage activation. 
ARACHIDONIC ACID OXYGENATION PRODUCTS

Macrophage membranes contain a high proportion of their total fatty acid content as arachidonic acid $(25 \%)$. This compares with a few per cent in other cell types. Phagocytic stimuli such as zymosan ${ }^{89}$ and antigen antibody complexes ${ }^{90}$ but not latex particles lead to the release of arachidonic acid by an inducible phospholipase. Cyclooxygenase and lipoxygenase then compete for the released arachidonic acid leading to the production of prostaglandins, hydroxyeicosatetraenoic acids and leukotrienes. ${ }^{91} 92$ The major prostaglandin products are $\mathrm{PGE}_{2}$ and 6-keto-prostaglandin $\mathrm{Fl} \alpha$. These products appear to be responsible for many of the inhibitory effects of macrophages (Table 4), which can be prevented by inhibiting prostaglandin synthesis with indomethacin..$^{93}$

There appear to be distinct regulatory mechanisms influencing the production of either prostaglandins or leukotrienes. ${ }^{92}$ Under certain conditions, large quantities of leukotriene $C$ (slow-reacting substance) are released by macrophages, suggesting that macrophages are involved in the vascular changes of immediate hypersensitivity reactions. Prostaglandins and leukotrienes also contribute to the inflammatory process through their influences on vascular tone and permeability.

The production of thymidine and arginase may have some importance in the cytostatic properties of macrophage-conditioned media. ${ }^{94}$

OXYGEN-DERIVED FREE RADICALS

In response to activation of macrophages by particulate or soluble inflammatory mediators, macrophages undergo a respiratory burst. This is associated with increased oxygen consumption and increased glucose metabolism via the hexose monophosphate shunt. In conjunction with these events macrophages secrete superoxide-anion $\left(\mathrm{O}_{2}-\right)$, hydrogen peroxide $\left(\mathrm{H}_{2} \mathrm{O}_{2}\right)$ and possibly hydroxyl radical $(\mathrm{OH})$, together with singlet oxygen $\left({ }^{1} \mathrm{O}_{2}\right) .{ }^{95}{ }^{96}$ Superoxide-anion is the major product $(90 \%)$ of initial oxygen consumption, hydrogen peroxide being derived by dismutation of $\mathrm{O}_{2}-.{ }^{97}$ The production of oxygen metabolites by macrophages is dependent on the site of isolation, the state of activation and the extent of differentiation of the cells. ${ }^{98}$

Primarily, these products are involved in the microbicidial activity of phagocytes. There is evidence, however, showing that oxygen metabolites released from activated macrophages damage endothelial cells, fibroblasts, ${ }^{99}$ tumour cells ${ }^{100}$ and platelets. In addition, free radicals may

Table 4 Effects of macrophage attributed to prostaglandin production ${ }^{4.3}$

Inhibitory

Mitogen-induced lymphocyte proliferation

Lymphokine production

Natural killer cell generation and activity

Killing by cytolytic $\mathrm{T}$ cells

Antibody-dependent cell cytotoxicity

Mixed leucocyte reaction

Stimulatory

Collagenase production

$\mathrm{T}$ cell osteoclast-activating factor production 
promote inflammation through the inactivation of serum inhibitors of protease activity resulting in increased tissue damage. ${ }^{101} 102$

A recent review by Janoff and Carp ${ }^{103}$ has discussed the experimental evidence supporting the view that oxidants released locally by leucocytes are able to inactivate $\alpha_{1}$-antitrypsin and mucus protease inhibitors. Proteases liberated at the sites of inflammation may then remain free to attack the tissue structures if high enough concentrations of oxidants are present. Superoxide also causes depolymerisation of hyaluronate, increasing its susceptibility to degradation by lysosomal enzymes. ${ }^{104}$ Thus, oxygen metabolites, either by themselves or in conjunction with lysosomal glycosidases and other proteases can injure the structural and cellular matrix of tissues.

The possible importance of these interactions has been shown using models of lung injury, where catalase and superoxide dismutase, inhibitors of hydrogen peroxide and superoxide activity respectively, reduce the degree of inflammation whereas antiproteases have little if any suppressive effect on the lung injury. ${ }^{105}$ Similar observations for superoxide dismutase have been made in chronic adjuvant arthritis in rats, autoimmune glomerulonephritis in mice ${ }^{106}$ and alveolitis. ${ }^{107}$ These studies support an important role for oxygen metabolites in both acute and chronic inflammation. Regulation of secretion by macrophages is summarised in Table 5.

\section{MACROPHAGE HETEROGENEITY}

Macrophages show a wide functional diversity and their capabilities vary with their state of maturation, their anatomical location and their degree of activation. Many aspects of these differing properties have been reviewed by Hopper and coworkers. ${ }^{59}$ Not only are there the changes related to maturation, but populations of cells that appear otherwise uniform can show marked variation in specific properties.

Metabolic assessment shows differences in specific activities of 5nucleotidase, acid phosphatase and synthesis of prostaglandins among a

\section{Table 5 Regulation of secretion by macrophages}

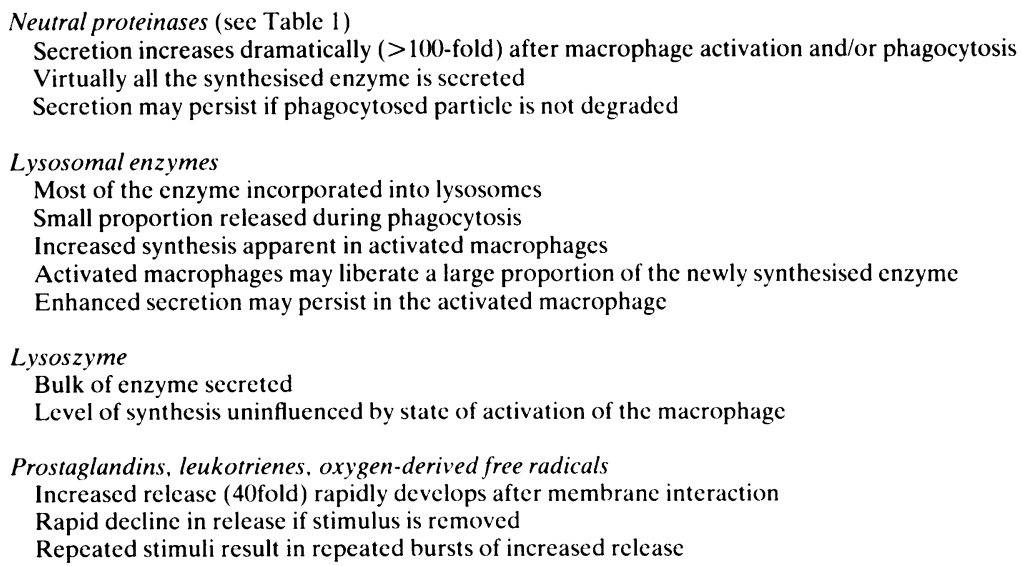


population of otherwise normal human monocytes. ${ }^{108}$ Under the same experimental conditions, the surface expression of immunological $\left(C_{3} b\right)$ receptors may be enhanced, ${ }^{30}$ whereas glycoprotein receptor expression may decrease. ${ }^{109}$ Surface expression of Ia antigens varies markedly among different macrophage populations. Splenic macrophages and circulating monocytes show a high degree of expression, whereas peritoneal and hepatic macrophages show much lower expression. ${ }^{110}$ Secretory activity of individual cells has been shown to vary widely. ${ }^{11}$

Alveolar macrophages have higher hydrolytic enzyme concentrations, a greater response to migration inhibitor factor, greater elastase production and lower $\mathrm{Fc}$ receptor expression than peritoneal macrophages. ${ }^{59}$ Peripheral blood monocytes show less secretory activity than Kupffer cells isolated simultaneously. ${ }^{112}$ Chemotactic responsiveness appears earlier and is more rapid in monocytes compared with resident macrophages, although a larger proportion of the latter cells may eventually respond. ${ }^{113}$

Using different experimental conditions, there may be alterations in the functional expression of activation. The induction of antimicrobial and antitumour activity can be completely separate. ${ }^{114}$ The interrelationship between macrophage subpopulations and other cells remains to be determined. Much of the available evidence indicates that recently recruited and activated macrophages are in many ways functionally superior to resident macrophages.

These variations in macrophage function and activity are obviously relevant in inflammatory bowel and liver disease. Newly recruited macrophages may well function quite differently when compared with old resident cells, and these aspects need to be considered when assessing any data on cells isolated from tissues.

\section{Gastrointestinal disease}

INFLAMMATORY BOWEL DISEASE

Both Crohn's disease and ulcerative colitis are chronic inflammatory disorders of the intestine of unknown aetiology. Macrophages are prominent in the inflammatory cell infiltrate in both conditions, but in Crohn's disease a hallmark of the condition is the granuloma, where macrophages are particularly conspicuous. Although the presence of granulomata might suggest a greater involvement for macrophages in Crohn's disease, kinetic studies have shown little difference between this condition and ulcerative colitis. Meuret and coworkers have studied patients with severe active Crohn's disease and ulcerative colitis. ${ }^{115}$ They have shown a monocytopoietic proliferative activity of 1.4 in Crohn's disease and 1.7 in ulcerative colitis (normal subjects, 1.0 ). This compares with figures of 3.5 in active tuberculosis and 1.1 in sarcoidosis, examples of high and low turnover granulomatous conditions.

It has been suggested that a basic defect in macrophage function might underlie the clinical differences between Crohn's disease and ulcerative colitis. ${ }^{116}$ Although there is an increased monocytosis in ulcerative colitis when compared with subjects with Crohn's disease, ${ }^{117}$ phagocytic activity of monocytes is not different between the conditions ${ }^{188} 119$ and bacterial killing appears to be normal. It should be noted that in both these studies monocytes showed enhanced phagocytosis of either Candida albicans ${ }^{118}$ or 
Staphylococcus aureus ${ }^{119}$ when compared with normal or disease controls. In both Crohn's disease and ulcerative colitis, random motility of monocytes is increased ${ }^{118}$ and one study ${ }^{120}$ shows a greater increase in subjects with Crohn's disease. Chemotaxis of monocytes towards either zymosan-activated serum ${ }^{118}$ or casein ${ }^{120}$ was significantly increased in ulcerative colitis and there was no defect in Crohn's disease when compared with normal controls. There is some evidence to suggest the presence of serum inhibitors of chemotaxis in Crohn's disease ${ }^{121}$ 122 which may explain these variable results. Alternatively, patients with ulcerative colitis show a higher monocyte turnover ${ }^{115}$ and therefore younger, more mobile cells may be present in the circulation.

In general, these studies confirm the presence of circulating monocytes which are functionally more active in inflammatory bowel disease with no evidence of a major macrophage defect in either condition. Small differences are probably explained by differences in experimental design.

In vivo assessment of macrophage function has been difficult. Migration of leucocytes into skin windows has been extensively studied ${ }^{123-\mathrm{P}^{26}}$ and although a reduced mobilisation of leucocytes, predominantly polymorphonuclear leucocytes, has been shown, macrophage accumulation appears normal. Studies concerning the numbers of cells at the inflammatory site have shown increased numbers of macrophages in both conditions $s^{127}$ and in one study significantly greater numbers in Crohn's disease. ${ }^{128}$ Together with the previous data, this suggests that more macrophages are destroyed or migrate to the lumen in ulcerative colitis. Crohn's disease would appear to be a more indolent condition with less macrophage destruction or loss.

Other evidence concerning the state of monocyte activation has come from studies on monocyte enzyme production in these conditions. Monocytes isolated from subjects with inflammatory bowel disease have higher lysosomal enzyme activities ( $\mathrm{N}$-acetyl- $\beta$-glucosaminidase, $\beta$-glucuronidase) than corresponding controls, ${ }^{8}{ }^{129}{ }^{130}$ indicating monocyte activation. ${ }^{44}$ The increase in cell-associated enzyme activity correlates with disease activity, especially in ulcerative colitis, where disease activity is more easy to define. ${ }^{129}$ Supernatant enzyme release by cultured monocytes is also raised, and this is increased further following exposure of the cells to endotoxin or zymosan, ${ }^{8}$ known macrophage activating agents. There appear to be some differences in the influence of various agents on the time course of enzyme release, in that immune complexes may initiate early release $^{9}$ and prolonged stimulation of synthesis, whereas endotoxin may only stimulate synthesis. ${ }^{89}$

Increased serum activity of lysosomal enzymes has also been observed in inflammatory bowel disease, ${ }^{129}$ but this does not correlate with disease activity. Serum lysosomal enzyme activity may arise from many other cells apart from macrophages. For all these observations there were no striking differences between ulcerative colitis and Crohn's disease. One recent study has indicated that the measurement of changes in enzyme activities in circulating monocytes underestimates the corresponding changes in macrophages isolated from the site of tissue injury. ${ }^{12}$ Thus the potential for greatly increased release of these enzymes, especially after exposure to various macrophage activating agents at the site of tissue injury, is apparent. Using ultracytochemical and immunohistological techniques, 
Otto and Gebbers ${ }^{131}{ }^{132}$ have shown the release of lysosomal enzymes (peroxidase, acid phosphatase) into the interstitial tissues in both Crohn's disease and ulcerative colitis. They speculate that this might be of pathogenetic significance in connection with the hypothesis of Weissmann, ${ }^{133} 134$ who originally suggested that lysosomal enzymes promote tissue damage. Perhaps the most striking observations in this respect are those of Abraham and his colleagues, ${ }^{135}$ who have shown that in the carrageenan-induced model of colitis in the guinea pig the tissue damage and ulceration are accompanied by an increase in the local release of macrophage lysosomal enzymes. They propose that these events are causally related. If this has any relevance to human disease, it would have important implications, as carrageenans are widely used in processed food.

Neutral proteinase secretion by cultured monocytes in inflammatory bowel disease has also been investigated. These enzymes may be even more important than lysosomal enzymes in promoting tissue damage as they are active at physiological $\mathrm{pH}$ and there is good experimental evidence to support their role in tissue damage. ${ }^{71}$ Doe and Dorsman ${ }^{136}$ have measured plasminogen activator release by cultured monocytes. They have shown a markedly enhanced release of this protease by monocytes from patients with Crohn's disease and ulcerative colitis compared with age matched controls. The increased release was greater in the Crohn's subjects and there was some correlation with disease activity. These findings are similar to those reported for lysosomal enzymes. Apart from the direct influence on their specific substrates, some neutral proteinases (for instance, plasminogen activator, a serine esterase) are able to promote injury through the generation of plasmin with subsequent fibrinolysis, complement activation, kinin generation and the inititation of the coagulation cascade. ${ }^{6}$

Studies by Rachmilewitz and coworkers have shown increased levels of transcobalamin II in peripheral blood monocytes of patients with inflammatory bowel disease, ${ }^{137}$ and this is further confirmation of monocyte activation in these conditions. It should be noted that these workers found even higher levels in subjects with shigellosis, indicating that the changes are in no way specific. More recent studies by the same group have shown enhanced prostanoid $\left(\mathrm{PGE}_{2}, \mathrm{PGI}_{2}, \mathrm{TXA}_{2}\right)$ production by inflamed rectal mucosa in inflammatory bowel disease, ${ }^{138}$ and these prostanoids originate from intestinal inflammatory cells. ${ }^{139}$ Studies using peripheral blood monocytes suggest that these changes at the site of inflammation reflect increased numbers of monocytes present. $\mathrm{PGE}_{2}$ secretion by individual monocytes did not differ between normals, Crohn's or ulcerative colitis. ${ }^{140}$ Differences were noted between Crohn's disease and ulcerative colitis when using peripheral blood mononuclear cells, $\mathrm{PGE}_{2}$ and $\mathrm{TXB}_{2}$ release being higher in active Crohn's disease, but this largely reflected the differing proportions of phagocytic cells in the peripheral blood mononuclear preparations.

To our knowledge, no direct studies of the role of oxygen radicals in inflammatory bowel disease have been published. A recent study on ischaemic injury in the cat small intestine, however, has indicated the importance of superoxide radicals. ${ }^{141}$ Superoxide dismutase and allopurinol pretreatment significantly reduced damage to the villus and crypt epithelium. It is therefore conceivable that macrophage generated 
oxygen radicals could promote injury directly in the gut as well as altering the local protease/antiprotease balance. ${ }^{103}$

The presence of increased numbers of activated monocytes in the circulation indicates that these cells have been exposed to circulating mediators such as lymphokines, endotoxin, complement fragments, or immune complexes. How these interactions apply at the tissue level still remains uncertain. It is interesting to observe that the drugs most commonly regarded as being effective in inflammatory bowel disease, glucocorticosteroids, azathioprine and salazopyrine, have profound effects on macrophage kinetics and biochemistry. Glucocorticosteroids induce a marked monocytopenia, ${ }^{142}$ reduce monocyte chemotaxis ${ }^{143}{ }^{144}$ and inhibit the secretion of neutral proteinases. ${ }^{145}$ Azathioprine induces a gradually cumulative monocytopenia, ${ }^{146}$ the result of decreased monocyte production, ${ }^{147}$ and reduces the influx of monocytes into sites of acute inflammation. ${ }^{146}$ Salazopyrine and its various products are able to influence monocyte chemotaxis ${ }^{146}$ and prostanoid production. ${ }^{148} 149$

No specific information on the role of macrophages in promoting fibrosis in inflammatory bowel disease is available, but this topic is discussed in general at the end of the section on liver disease. Recent publication of improved methods of isolating macrophages from colonic tissue with reasonable yields ${ }^{150}$ should lead to a better understanding of the relationships between monocytes, macrophages, granulomas and inflammatory bowel disease.

ACUTE AND CHRONIC LIVER DISEASE

Many factors and aetiological agents are involved in the development of hepatic damage. ${ }^{151}$ Most studies on macrophage function in liver disease have concentrated on differences between cirrhosis, of whatever aetiology, and normals. In no particular condition are macrophages regarded as the most prominent infiltrating cells. Nevertheless, they comprise a substantial proportion of the cells in various forms of chronic active hepatitis.

Monocyte kinetic studies in human liver disease have been difficult to interpret $^{152}$ and as far as we are aware there are no clear data on the subject. In the normal steady state, around $50 \%$ of monocytes leaving the circulation become hepatic macrophages, Kupffer cells. ${ }^{16}$ Labelling studies in animals have shown a marked increase in monocyte recruitment into the liver in hepatic inflammation, in response to a variety of stimuli. ${ }^{153}{ }^{154} \mathrm{In}$ various forms of liver disease, circulating monocyte numbers do not differ from normal. ${ }^{155}$ It has been well shown, however, that circulating monocyte numbers return rapidly to normal once the initial inflammatory insult has subsided, ${ }^{153}$ and it may be that the sampling time in this particular study has influenced the result, as the majority of subjects did not have active inflammation. Chemotaxis is defective in cirrhotic patients, affecting all leucocytes, ${ }^{29} 156$ and has been attributed to the presence of serum inhibitors of chemotaxis or inactivators of chemotactic factors. This chemotactic defect has been shown for monocytes from patients with cirrhosis $^{155} 157$ and is caused by circulating inhibitory factors, as the same cells function normally in the presence of normal serum. Similarly, there is reduced monocyte bacterial phagocytosis, bacterial killing and spreading in cirrhotic subjects. ${ }^{155} 158$ Although many of these observations have been made in alcoholic liver disease, a number of these studies have included 
substantial numbers of patients with liver disease of a different aetiology, and it would seem that these changes reflect the secondary effects of cirrhosis.

Of more relevance to the present review have been the observations on macrophage secretory activity in liver disease. Initially, monocytes from patients with chronic liver disease were shown to release enhanced quantities of lysosomal enzymes, ${ }^{8}$ especially on exposure to zymosan or endotoxin, although a more recent study from the same laboratory has failed to confirm this. ${ }^{155}$ As in inflammatory bowel disease, these findings might indicate that macrophages are being exposed in the circulation to activating agents. In acute hepatitis and active cirrhosis, free lysosomal enzyme activity in the liver is raised. ${ }^{159} 160$ Recent studies from Japan would indicate that this enzyme activity could arise from macrophages and not from damaged hepatocytes. ${ }^{161}$ It may therefore be important to correlate monocyte enzyme activity both with the activity of the liver disease and the histological features. Holdstock and coworkers ${ }^{155}$ have provided some information on this point and it is interesting to note that raised monocyte enzyme activity was seen in a group of "cirrhotics on steroids', in contrast to the other groups of liver disease. The latter included most of the patients with chronic active hepatitis, a group where macrophage infiltration within the liver is more prominent. Overall, enzyme release from monocytes of cirrhotic patients tended to be diminished and was associated with the predominance of an alcoholic aetiology.

Other studies on macrophage enzyme release and hepatic inflammation have involved the use of animal models. Ferluga and Allison, using a mouse model, ${ }^{7}$ first suggested that macrophages recently recruited into the liver could be further activated, resulting in the release of products toxic to parenchymal cells. A rat model using Corynebacterium parvum to induce hepatic granulomas and portal tract infiltration has been developed by ourselves, and macrophages isolated from these livers show markedly enhanced concentrations of lysosomal enzyme and neutral proteinase release compared with resident Kupffer cells. ${ }^{10} 162$ Although only a single lysosomal enzyme ( $\mathrm{N}$-acetyl- $\beta$-glucosaminidase) and neutral proteinase were measured in these studies, it is probable that the production of a wide range of lysosomal enzymes (acid phosphatase, $\beta$-glucuronidase, cathepsin $\mathrm{D}, \beta$-glucosidase, $\beta$-galactosidase) and neutral proteinases (collagenase, elastase) are similarly increased by these activated cells. ${ }^{163}$ A sequence of monocyte/macrophage activation in terms of enzyme release can be seen as monocytes are recruited into the liver and exposed locally to macrophageactivating agents. ${ }^{164}$ As previously stated, simultaneous measurement of monocyte and tissue macrophage enzyme activity has shown that assessment of the former underestimates the magnitude of the change at the site of tissue injury. ${ }^{112}$

No direct proof of the importance of these products in promoting hepatocyte damage is available. The fact, however, that hepatocytes in culture survive longer and show fewer morphological changes if antiproteases are included in the culture media ${ }^{165}$ and the significant association of $\alpha_{1}$-antitrypsin deficiency with human liver disease ${ }^{166}$ suggests that the release of these enzymes does have some relevance. Studies on murine viral hepatitis have implicated lysosomal enzyme release in the 
initiation and perpetuation of hepatic necrosis. ${ }^{167} 168$ Thus, there is a great deal of circumstantial evidence that these enzymes could promote tissue injury in hepatic disease.

In chronic liver disease, many factors may be involved in monocyte recruitment into the liver. Recent histological studies have confirmed the transition of monocytes to tissue macrophages within the liver, using glucan to recruit the cells. ${ }^{169}$ Macrophage enżyme release will be raised after exposure to activating agents. These agents may arise locally or be present in portal blood. Monocytes have been shown to release more lysosomal enzymes after incubation with portal serum when compared with systemic serum simultaneously obtained. ${ }^{170}$ This difference correlated well with the presence of immune complexes $(\operatorname{IgG}, \operatorname{IgA})$ in portal blood but not with the presence of endotoxin or complement levels. Monocytes once recruited into the liver could promote further damage on exposure to appropriate activating agents in portal blood.

Whether Kupffer cells are involved in hepatic injury is difficult to determine. Although there is some limited evidence that active Kupffer cell phagocytosis can result in local hepatocyte damage, ${ }^{171}$ other studies have indicated that blockade of Kupffer cell phagocyte function results in hepatocyte damage. ${ }^{172} 173$ Presumably this is the result of exposure of hepatocytes to various toxic products. Kupffer cell phagocytic function in man is very variable, depending on the disease process. In obstructive jaundice and alcoholic hepatitis, function is commonly depressed, whereas it is increased in other forms of chronic hepatocellular inflammation. ${ }^{174}$ Effective Kupffer cell function is depressed in liver disease, either because of portacaval shunting or because Kupffer cells are directly affected by agents such as viruses or alcohol. ${ }^{175}$ This may lead to systemic endotoxinaemia and immune complex persistence and these may be responsible for some of the manifestations of liver disease such as clotting disorders and renal failure. ${ }^{176}$ Although there has been some dispute concering endotoxinaemia in liver disease, ${ }^{177}$ most authors agree that this is a common finding. ${ }^{176} 178$ The persistence of endotoxin could lead to complement activation via the alternate pathway, increased plasma lysosomal enzyme activity ${ }^{179}$ and macrophage activation. It is interesting to note that Hirata and coworkers have shown that endotoxin administration results in a rapid rise in hydrolytic enzyme activity derived from sinusoidal cells. Degenerative changes occur in the parenchymal cells after this rise in hydrolytic enzyme activity. Thus, blockade of Kupffer cells activity could result in increased enzyme release by recently recruited macrophages. Results from our laboratory indicate that recently recruited macrophages are more active secretory cells than old resident Kupffer cells. ${ }^{162} \mathrm{~A}$ further consequence of altered Kupffer cell function in liver disease is the alterations in cell-mediated and humoral immunity. Some aspects of this have recently been reviewed by Rogoff and Lipsky. ${ }^{180}$

No experimental data have been published on toxic oxygen metabolites and hepatic injury, although for other reasons free radical scavengers such as $(+)$-cyanidanol-3 have been used in liver disease ${ }^{181}$ with no apparent benefit.

Macrophages are involved in the remodelling of embryonic tissues and through the release of various neutral proteinases can influence connective tissue deposition. A subpopulation of human monocytes $(8-20 \%)$ can 
express fibrin as part of their activity in inflammatory lesions. ${ }^{182}$ This can serve as a substrate for fibronectin, which precedes the appearance of collagen in connective tissue remodelling. ${ }^{183}$ Liver macrophages contain fibronectin and Type I collagen. ${ }^{184} \mathrm{~A}$ recent preliminary report suggests that macrophage factors are involved in the recruitment of fibroblasts to the liver during inflammation. ${ }^{185}$ This area may warrant further, more intensive study.

Overall, the studies of macrophage function in liver disease have not shown any consistent abnormalities apart from evidence of depressed Kupffer cell function. It is clear that in human liver disease accurate assessment of macrophage activity will only be obtained by studying specific disease groups and avoiding the broad categories that have been studied up to now. In experimental models the potential for enzyme and other secretory product release is apparent, but it is still unclear as to whether this is relevant to any particular condition. As indicated earlier, the association between $\alpha_{1}$-antitrypsin deficiency and human liver disease suggests some role for proteolytic enzymes. The involvement of liver sinusoidal cells, especially fat storing cells and macrophages, in collagen metabolism ${ }^{186} 187$ suggests that these cells may play an important role in fibrosis control and the development of cirrhosis.

\section{Conclusion}

There is no doubt that macrophages play a prominent role in a variety of chronic inflammatory conditions. Evidence has been presented to indicate that, especially in inflammatory bowel disease, circulating monocytes are in an activated state. This probably reflects the presence in the circulation of a number of macrophage-activating agents, such as immune complexes, complement components, endotoxin, and lymphokines. Recruitment of these monocytes to the sites of tissue injury is evident both on histological grounds and on kinetic data. The potential for the release of a number of macrophage secretory products at the site of tissue injury has been shown and products such as antiproteases and free radical scavengers are able to modify the inflammatory response both experimentally and in nature. These cells probably contribute to tissue damage in gastrointestinal disease, but it is not evident at present how significant this contribution is. Further studies are required on the modification of inflammation in experimental models, on the relevance of these findings in human disease using immunohistological techniques and on the involvement of macrophages in hepatic fibrosis. Although this review has been concerned with specific areas of macrophage activity, other cellular interactions by macrophages are also of major significance and it is hoped that this report will help to stimulate further work in all these areas.

We should like to thank Mrs Isabella Strachan for her care in preparing this manuscript.

A R TANNER, M J P ARTHUR, AND RALPH WRIGHT

From the Professorial Medical Unit Level D

Southampton General Hospital

Tremona Road

Southampton SO9 $4 X Y$ 


\section{References}

1 Territo M, Cline MJ. Macrophages and their disorders in man. In: Nelson DS, ed. Immunobiology of the macrophage. London: Academic Press, 1976: 593-616.

2 Rodey GE, Park BH, Windhorst DB. Good RA. Defective bactericidal activity of monocytes in fatal granulomatous disease. Blood 1969; 33: 813-20.

3 Cline MJ. Defective mononuclear phagocyte function in patients with myelomonocytic leukaemia and in some patients with lymphoma. J Clin Invest 1973; 52: 2185-90.

4 Drutz DJ, Cline MJ, Levy L. Leukocyte antimicrobial function in patients with leprosy. J Clin Invest 1974; 53: 380-6.

5 Davies P. Allison AC. Secretion of macrophage enzymes in relation to the pathogenesis of chronic inflammation. In: Nelson DS, ed. Immunobiology of the macrophage. London: Academic Press, 1976: 427-61.

6 Gordon S, Newman W, Bloom B. Macrophage proteases and rheumatic diseases: regulation of plasminogen activator by thymus-derived lymphocytes. Agents Actions 1978; 8: 19-26.

7 Ferluga J, Allison AC. Role of mononuclear infiltrating cells in pathogenesis of hepatitis. Lancet 1978; 2: 610-1.

8 Ganguly NK. Lloyd B. Price CP. Kingham JGC. Lloyd RS, Triger DR. Wright R. Acid hydrolases in monocytes from patients with inflammatory bowel disease. chronic liver disease and rheumatoid arthritis. Lancet 1978; 1: 1073-5.

9 Mee AS, Nuttall L, Potter BJ, Jewell DP. Studies on monocytes in inflammatory bowel disease: factors influencing monocyte lysosomal enzyme activity. Clin Exp Immunol 1980; 39: 785-91.

10 Tanner A, Keyhani A. Reiner R, Holdstock G, Wright R. Proteolytic enzymes released by liver macrophages may promote hepatic injury in a rat model of hepatic damage. Gastroenterology 1981; 80: 647-54.

11 Quesenberry P. Levitt L. Haematopoietic stem cells II. N Engl J Med 1979; 301: 819-23.

12 Whitelaw DM. Observations on human monocyte kinetics after pulse labelling. Cell Tissue Kinet 1972; 5: 311-7.

13 Fleidner TM, Laeger F, Cronkite EP. Zytokinetische untersuchungen an menschlichen Blutmonozyten. Haemat Blutt Transfus 1969; 7: 39-51.

14 Roser B. The distribution of intravenously injected Kupfer cells in the mouse. J Reticuloendothel Soc 1968; 5: 455-71.

15 Volkman A. Disparity in origin of mononuclear phagocyte populations. $J$ Reticuloendothel Soc 1976; 19: 249-68.

16 Croften RW, Martina MC. Diesselhoff-Den Dulk MMC, van Furth R. The origins. kinetics and characteristics of the Kupffer cells in the normal steady state. J Exp Med 1978; 148: $1-17$.

17 Anonymous. Bone marrow origin of Kupffer cells. Lancet 1980; 1: 131-2.

18 Warr GW, Sljivic US. Origin and division of liver macrophages during stimulation of the mononuclear phagocyte system. Cell Tissue Kinet 1974: 7: 559-65.

19 Deimann W, Fahimi HD. The appearance of transition forms between monocytes and Kupfer cells in the liver of rats treated with glucan: a cytochemical and ultra-structural study. J Exp Med 1979; 149: 883-97.

20 Volkman A. Monocyte kinetics and their changes in infection. In: Nelson DS, ed. Immunobiology of the macrophage. London: Academic Press, 1976: 291-322.

21 Schmitt E, Meuret G, Stix L. Monocyte recruitment in tuberculosis and sarcoidosis. Br J Haematol 1979; 35: 11-7.

22 Triger DR, Wright R. Hyperglobulinaemia in liver disease. Lancet 1973; 1: 1496-6.

23 Ando M, Dannenberg AM. Macrophage accumulation, division. maturation and digestive and microbicidal capacities in tuberculous lesions IV. Lab Invest 1972; 27: $466-72$.

24 Anderson SE, Remington JS. Effect of normal and activated human macrophages on Toxoplasma gondii. J Exp Med 1974; 139: 1154-74.

25 Shahar A, Kletter Y, Aronson M. Granuloma formation in cryptococcosis. Israel J Med Sci 1969; 5: 1164-72.

26 Mackaness GB. Cellular resistance to infection. J Exp Med 1962; 116: 381-406.

27 Snyderman R. Mergenhagen SE. Chemotaxis of macrophages. In: Nelson DS, ed. Immunobiology of the macrophage. London: Academic Press, 1976: 323-48.

28 Snyderman R, Pike C. An inhibitor of macrophage chemotaxis produced by neoplasms. Science 1976; 192: 370-2. 
29 Maderazo EG, Ward PA, Quintiliani R. Defective regulation of chemotaxis in cirrhosis. $J$ Lab Clin Med 1975; 85: 621-30.

30 Glass EJ. Kay AB. Enhanced expression of human monocyte complement (C3b) receptors by chemoattractants. Clin Exp Immunol 1980; 39: 768-75.

31 Stossel TP. The mechanism of phagocytosis. J Reticuloendothel Soc 1976; 19: 237-45.

32 Cline MJ. Bactericidal activity of human macrophages: analysis of factors influencing the killing of Listeria monocytogens. Infect Immun 1970; 2: 156-61.

33 Johnston RB, Godzik CA, Cohn ZA. Increased superoxide anion production by immunologically activated and chemically elicited macrophages. J Exp Med 1978; 148: 115-27.

34 Davis GS. Mortara M, Pfeiffer LM, Green GM. Bactericidal and biochemical peroxidase activity in human alveolar macrophages. Am Rev Resp Dis 1977; 115: $210 \mathrm{~A}$.

35 Dannenberg JM. Macrophages in inflammation and infection. N Engl J Med 1975; 293: 489-93.

36 Hocking WG, Golde DW. The pulmonary alveolar macrophage I. $N$ Engl J Med 1975; 301: $580-7$.

37 Maruta H. Mizuno D. Selective recognition of various erythrocytes in endocytosis by mouse peritoneal macrophages. Nature 1971; 234: 246-8.

38 Cohen AB. Gold WM. Defence mechanisms of the lungs. Ann Rev Physiol 1975; 37: $325-50$.

39 Golde DW. Cline MJ. Identification of the colony-stimulating cell in human peripheral blood. J Clin Invest 1972; 51: 2981-3.

40 Broxmeyer HE. Smithyman A. Eger RR. Meyers RA. De Sousa M. Identification of lactoferrin as the granulocyte-derived inhibitor of colony-stimulating activity production. $J$ Exp Med 1978; 148: 1052-67.

41 Kurland JI, Bockman RJ, Broxmeyer HE, Moore MAJ. Limitation of excessive myelopoiesis by the intrinsic modulation of macrophage-derived prostaglandin $\mathrm{E}$. Science 1978; 199: 552-5.

42 Gordon LI, Miller WJ, Brandon RF, Zanjani ED, Jacob HJ. Regulation of erythroid colony formation by bone marrow macrophages. Blood 1980; 55: 1047-50.

43 Unanue ER. The regulatory role of macrophages in antigenic stimulation II. Symbiotic relationship lymphocytes and macrophages. Adv Immunol 1981; 31: 1-136.

44 Unanue ER. Secretory function of mononuclear phagocytes. Am J Pathol 1976; 83: 396-417.

45 Nogueira N. Gordon S, Cohn Z. Trypansoma Cruzi: the induction of macrophage plasminogen activator requires thymus-derived lymphocytes. J Exp Med 1977; 146: $172-83$

46 Gordon S, Unkeless JC, Cohn ZA. Induction of macrophage plasminogen activator by endotoxin stimulation and phagocytosis: evidence for a two-stage process. $J$ Exp Med 1974; 140: $995-1010$.

47 North RJ. The concept of the activated macrophage. J Immunol 1978; 121: 806-9.

48 David JR. Macrophage activation by lymphocyte mediators. Fed Proc 1975; 34: 1730-6.

49 Alexander P. Evans R. Endotoxin and double-stranded RNA render macrophages cytotoxic. Nature (New Biol) 1971; 232: 76-8.

50 Schorlemmer HU. Allison AC. Effects of activated complement components on enzyme secretion by macrophages. Immunol 1976; 31: 781-8.

51 Evans R, Alexander P, Mechanism of extracellular killing of nucleated mammalian cells by macrophages. In: Nelson DJ, ed. Immunobiology of the macrophage. London: Academic Press. 1976: 535-76.

52 Schultz RM. Papametheakis JD, Chirigos MA. Interferon: an inducer of macrophage activation by polanions. Science 1977; 197: 674-6.

53 Ogmundsdottir HM, Weir DM. Mechanisms of macrophage activation. Clin Exp Immunol 1980: 40: 223-34.

54 Karnovsky ML, Lazdins JK. Biochemical criteria for activated macrophages. J Immunol 1978; 121: 809-13.

55 Christie $\mathrm{GH}$, Bomford $\mathrm{R}$. Mechanisms of macrophage activation by Corynebacterium parvum I. In vivo experiments. Cell Immunol 1975: 17: 141-9.

56 Ruco LP, Meltzer MS. Macrophage activation for tumoricidal toxicity: development of macrophage cytotoxic activity requires completion of a sequence of short-lived intermediary reactions. J Immunol 1978; 121: 2035-42.

57 Koren HS, Meltzer MS, Adams PO. The ADCC capacity of macrophages from C3H/HeJ and A/J mice can be augmented by BCG. J Immunol 1981; 126: 1013-5. 
58 Ruco LP, Meltzer MS. Macrophage activation for tumor cytotoxicity: increased lymphokine responsiveness of peritoneal macrophages during acute inflammation. J Immunol 1978; 120: 1054-62.

59 Hopper KE, Wood PR, Nelson DS. Macrophage heterogeneity. Vox Sang 1979; 36: 257-74.

60) Cohn ZÁ, Fedorko MD, Hirsch JG. The in vitro differentiation of mononuclear phagocytes V. The formation of macrophage lysosomes. J Exp Med 1966; 123: 757-66.

61 Davies P, Page RC, Allison AC. Changes in cellular enzyme levels and extracellular release of lysosomal acid hydrolases in macrophages exposed to Group A streptococcal cell wall substance. $J$ Exp Med 1974; 139: 1262-81.

62 Schnyder J, Baggiolini M. Role of phagocytosis in the activation of macrophages. $J$ Exp Med 1978; 148: 1449-57.

63 Schorlemmer HU, Davies P, Hylton W, Gugig M, Allison AC. The selective release of lysosomal acid hydrolases from mouse peritoneal macrophages by stimuli of chronic inflammation. Br J Exp Pathol 1977; 58: 315-26.

64 Cardella CJ, Davies P, Allison AC. Immune complexes induce selective release of lysosomal hydrolases from macrophages in vitro. Nature (Lond) 1974; 247: 46-8.

65 Pantalone RM, Page RC. Lymphokine-induced production and release of lysosomal enzymes by macrophages. Proc Natl Acad Sci USA 1975; 72: 2091-4.

66 Geisow M. A carbohydrate signal for intracellular transit. Nature 1981; 290: 15.

67 Page RC, Davies P. Allison AC. Participation of mononuclear phagocytes in chronic inflammatory diseases. J Reticuloendothel Soc 1974; 15: 413-38.

68 Unkeless JC, Gordon S, Reich E. Secretion of plasminogen activator by stimulated macrophages. J Exp Med 1974; 139: 834-50.

69 Werb Z, Gordon S. Secretion of a specific collagenase by stimulated macrophages. J Exp Med 1975; 142: 346-50.

70 Werb Z, Gordon S. Elastase secretion by stimulated macrophages. J. Exp Med 1975; 142: 361-77.

71 Werb Z, Banda MJ, Jones PA. Degradation of connective tissue matrices by macrophages I. Proteolysis of elastin, glyco-proteins and collagen by proteinases isolated from macrophages. J Exp Med 1980; 152: 134()-57.

72 Buermann CW, Oronsky AL, Horowitz AI. Chondroitin sulfate degrading enzymes in human polymorphonuclear lymphocytes: characteristics and evidence for concerted mechanism. Arch Biochem Biophys 1979; 193: 277-84.

73 Keuppers F, Bearn AG. A possible experimental approach to the association of hereditary alpha-l-antitrypsin deficiency and pulmonary emphysema. Proc Soc Exp Bioi Med 1966; 121: 1207-9.

74 Lieberman $\mathbf{J}$. Heterozygous and homozygous alpha-l-antitrypsin deficiency in patients with pulmonary emphysema. $N$ Engl J Med 1969; 281: 279-84.

75 Klasen EC, Biemond I, Weterman IT. Alpha-l-antitrypsin levels and phenotypes in Crohn's disease in the Netherlands. Gut 1980; 21: 840-2.

76 Friedland J, Setton C, Silverstein E. Angiotensin converting enzyme: induction by steroids in rabbit alveolar macrophages in culture. Science 1977; 197: 64-5.

77 Alitalo C, Hovi T, Vaheri A. Fibronectin is produced by human macrophges. J Exp Med 1980; 151: 602-13.

78 Edwards RL, Rickles FR, Bobrove AM. Mononuclear cell tissue factor: cell of origin and requirements for activation. Blood 1979; 54: 359-70.

79 Wyatt HV, Colten HR, Borsos T. Production of the second (C2) and fourth (C4) components of guinea-pig complement by single peritoneal cells: evidence that one cell may produce both components. J Immunol 1972; 108: 1609-14.

80 Roberts NJ, Douglas RG, Simons RM. Diamond ME. Virus-induced interferon production by human macrophages. J Immunol 1979; 123: 365-9.

81 Neumann C, Sorg C. Immune interferon I. Production by lymphokine-activated murine macrophages. Eur J Immunol 1977; 7: 719-25.

82 Sonnenfeld G, Mandel AD, Merigan TC. In vitro production and cellular origin of murine type II interferon. Immunology 1979; 36: 883-90.

83 Gordon S, Todd J, Cohn ZA. In vitro synthesis and secretion of lysozyme by mononuclear phagocytes. J Exp Med 1974: 13a: 1228-48.

84 Chipman DM, Sharon N. Mechanism of lysozyme action. Science 1969: 165: 454-65.

85 Gordon LI, Douglas SD, Kay NE. Yamada O. Ossermann EF. Jacob HS. Modulation of neutrophil function by lysozyme. Potential negative feedback system of inflammation. J Clin Invest 1979; 64: 226-32. 
86 Hovi T. Mosher D. Vaheri A. Cultured human monocytes synthesise and secrete a2-macroglobulin. J Exp Med 1977: 145: 158(1-9.

87 Isaacson P. Jones DB. Millward-Sadler GH. Judd MA. Payne S. Alpha-l-antitrypsin in human macrophages. J (lin Pathol 1981: 34: 982-90).

88 Polverini PJ. Cotran RS. Gimbrone MA. Unanue ER. Activated macrophages induce vascular proliferation. Nature 1977: 269: 804-6.

89 Rouzer CA. Scott WA. Hamill AL. Cohn ZA. Dynamics of leukotriene C production by macrophages. $J$ Exp Med 198(): 152: 1236-47.

9() Humes JL. Bonney RJ. Pelus L. Dahlgren ME. Sadowski SJ, Kuehl FA. Davies P. Macrophages synthesise and release prostaglandins in response to inflammatory stimuli. Nature 1977: 269: 149-51.

91 Scott WA. Zrike JM. Hamill AL. Kempe J, Cohn ZA. Regulation of arachidonic acid metabolites in macrophages. J Exp Med 1980: 152: 324-35.

92 Rouzer CA. Scott WA. Hamill AL. Liu F. Katz DH. Cohn ZA. Secretion of leukotriene $C$ and other arachidonic acid metabolites by macrophages challenged with immunoglobulin E immune complexes. J Exp Med 1982: 156: 1077-86.

93 Goodwin JS. Bankhurst AD. Messner RP. Suppression of human T cell mitogenesis by prostaglandin. J Exp Med 1977: 146: 1719-34.

94 Calderan J. Unanue ER. Two biological activities regulating cell proliferation found in cultures of peritoneal exudate cells. Nature 1975: 253: 359-61.

95 Johnston RB. Chadwick DA. Pabst MJ. Release of superoxide anion by macrophages: effect of in vivo or in vitro priming. In: van Furth R. ed. Mononuclear phagocytes II. The Hague: Martinus Nijhoff. 1980: 1143-63.

96 Nathan CJ. The release of hydrogen peroxide from mononuclear phagocytes and its role in extracellular cytolysis. In: van Furth R. ed. Mononuclear phagocytes II. The Hague: Martinus Nijhoff. 1980: 1165-86.

97 Fantone JC. Ward PA. Role of oxygen-derived free radicals and metabolites in leukocyte-dependent inflammatory reactions. Am J Pathol 1982: 107: 397-418.

98 Johnston RB. Godzik CA. Cohn ZA. Increased superoxide anion production by immunologically activated and chemically elicited macrophages. J Exp Med 1978; 148: $115-27$

99 Simon RH. Scoggin CH. Patterson D. Hydrogen peroxide causes the fatal injury to human fibroblasts exposed to oxygen radicals. J Biol Chem 1981; 256: 7181-86.

1(0) Nathan CF. Brukner L. Silverstein SC. Cohn ZA. Extracellular cytolysis by activated macrophages and granulocytes. J Exp Med 1975; 149: 84-113.

101 Carp H. Janoff A. In vitro suppression of serum elastase inhibitory capacity by reactive oxygen species generated by phagocytosing polymorphonuclear leucocytes. J Clin Invest 1979: 63: 793-7.

102 Matheson NR. Wong DS. Travis J. Enzymatic inactivation of human alpha-l-proteinase inhibitor by neutrophil myeloperoxidase. Biochem Biophys Res Commun 1979; 88: $4(1)-9$.

103 Janoff A. Carp H. Proteases, antiproteases and oxidants: pathways of tissue injury during inflammation. Monogr Pathol 1982; 23: 62-82.

104 Greenwald RA. Moy WW. Effect of oxygen-derived free radicals on hyaluronic acid. Arthritis Rheum 198(); 23: 455-63.

105 Johnson KJ. Ward PA. Role of oxygen metabolites in immune complex injury of the lung. J Immunol 1981: 126: 2365-9.

106 Huber W. Saifer MG. Orgotein. The drug version of bovine $\mathrm{Cu}-\mathrm{Zn}$ superoxide dismutase. In: Michelson AM. McCord JM. Fridovich I, eds. A summary account of safety and pharmacology in laboratory animals, superoxide and duperoxide dismutase. New York: Academic Press. 1977: 517-34.

107 Katzenstein A. Bloor CM. Liebow A. Diffuse alveolar damage: the role of oxygen shock and related factors. Am J Pathol 1976: 85: 210-28.

108 Picker LJ. Raff HV. Goldyne ME. Stobo JD. Metabolic heterogeneity among human monocytes and its modulation by GE. J Immunol 1980): 124: 2557-62.

109 Ezekowitz RAB. Austyn J. Stahl PD. Gordon S. Surface properties of BCG-activated mouse macrophages. J Exp Med 1981; 154: 60-76.

110 Cowing C. Schwartz BD. Dickler HB. Macrophage Ia antigens. Macrophage populations differ in their expression of Ia antigens. J Immunol 1978: 120: 378-84.

111 Goldberg AR. Increased protease levels in transformed cells: a casein overlay assay for the detection of plaminogen activator production. Cell 1974: 2: 95-102.

112 Reiner RG. Tanner AR. Keyhani AH. Wright R. A comparative study of lysosomal 
activity in monocytes and Kupffer cells isolated simultaneously in a rat model of liver injury. Clin Exp Immunol 1981; 43: 376-9.

113 Boumsell L. Meltzer MJ. Mouse mononuclear cell chemotaxis. Differential response of monocytes and macrophages. J Immunol 1975; 115: 1746-8.

114 Wing EJ, Gardner ID, Ryning FW, Remington JS. Dissociation of effector functions in populations of activated macrophages. Nature (Lond) 1977; 268: 642-4.

115 Meuret G, Bitzi A. Hammer B. Macrophage turnover in Crohn's disease and ulcerative colitis. Gastroenterology 1978; 74: 501-3.

116 Ward M. The pathogenesis of Crohn's disease. Lancet 1977; 2: 903-5.

117 Mee AS, Berney J, Jewell DP. Monocytes in inflammatory bowel disease: absolute monocyte counts. J Clin Pathol 1980; 33: 917-20.

118 Whorwell PJ, Bennett P. Tanner AR, Wright R. Monocyte function in Crohn's disease and ulcerative colitis. Digestion 1981; 22: 271-5.

119 Mee AS. Szawatakowski M, Jewell DP. Monocytes in inflammatory bowel disease: phagocytosis and intracellular killing. J Clin Pathol 1980; 33: 921-5.

120 Rhodes JM, Jewell DP. Motility of neutrophils and monocytes in Crohn's disease and ulcerative colitis. Gut 1983; 24: 73-7.

121 Rhodes JM, Potter BJ, Brown DJC, Jewell DP. Serum inhibitors of leucocyte chemotaxis in Crohn's disease and ulcerative colitis. Gastroenterology 1982; 82: 1327-34.

122 D’Amelio R, Rossi P, Le Moli S, Ricci R, Montano S, Pallone F. In vitro studies on cellular and humoral chemotaxis in Crohn's disease using the under agarose gel technique. Gut 1981; 22: 566-70.

123 Segal AW, Loewi G, Neutrophil dysfunction in Crohn's disease. Lancet 1976; 2: 219-21.

124 Morain CO, Segal AW, Walker D, Levi AJ. Abnormalities of neutrophil function do not cause the migration defect in Crohn's disease. Gut 1981; 22: 817-22.

125 Wandall JH, Binder V. Leucocyte function in Crohn's disease. Gut 1982; 23: 173-80.

126 Wandall JH, Binder V. Leucocyte function in ulcerative colitis. Gut 1982; 23: 758-65.

127 Bookman MA, Bull DM. Characteristics of isolated intestinal mucosal lymphoid cells in inflammatory bowel disease. Gastroenterology 1979; 77: 503-10.

128 MacDermott RP, Franklin GO, Jenkins KM, Kodner IJ, Nash GS, Weinreib IJ. Human intestinal mononuclear cells I. Investigation of antibody dependent, lectin induced and spontaneous cell mediated cytotoxic capabilities. Gastroenterology 1980; 78: 47-56.

129 Mee AS, Jewell DP. Monocytes in inflammatory bowel disease: monocyte and serum lysosomal enzyme activity. Clin Sci 1980; 58: 295-300.

130 Doe WF, Temple C, Dorsman B, Golder J. Activation of mononuclear phagocytes in chronic inflammatory bowel disease. Gastroenterology 1980; 78: 1158A.

131 Otto HF, Gebbers J-O. Electron microscopic, ultracytochemical and immunohistological observations in Crohn's disease of the ileum and colon. Virchows Arch [Pathol Anat] 1981; 391: 189-205.

132 Gebbers J-O, Otto HF. Evidence for local immune complexes in ulcerative colitis. Acta Gastroenterol Belg 1978; 41: 329-50.

133 Weissmann G. Lysosomes, autoimmune phenomena and diseases of connective tissue. Lancet 1964; 2: 1373-9.

134 Weissmann G, Smolen JE, Korchak HM. Release of inflammatory mediators from stimulated neutrophils. $N$ Engl J Med 1980; 303: 27-34.

135 Abraham R, Fabian RJ, Golberg L, Coultson F. Role of lysosomes in carrageenaninduced cecal ulceration. Gastroenterology 1974; 67: 1169-81.

136 Doe WF, Dorsman B. Chronic inflammatory bowel disease: increased plasminogen activator secretion by mononuclear phagocytes. Clin Exp Immunol 1982; 48: 256-60.

137 Rachmilewitz D, Ligumsky M, Rachmilewitz B, Rachmilewitz M, Tarcic N, Schlesinger M. Transcobalamin II level in peripheral blood monocytes - a biochemical marker in inflammatory disease of the bowel. Gastroenterology 1980; 78: 43-6.

138 Ligumsky M, Karmeli F, Sharon P, Zor U, Cohen F, Rachmilewitz D. Enhanced thromboxane $\mathrm{A}_{2}$ and prostacyclin production by cultured rectal mucosa in ulcerative colitis and its inhibition by steroids and sulfasalazine. Gastroenterology 1981; 81: 444-9.

139 Rachmilewitz D, Zifreni A, Ligumsky M, Sharon P, Treves A. Enhanced prostanoid synthesis by cultured blood mononuclear and intestinal lymphoid cells in Crohn's disease. Gastroenterology 1981; 80: 1256A.

140 Rachmilewitz D, Ligumsky M, Haimovitz A, Treves AJ. Prostanoid synthesis by cultured peripheral blood mononuclear cells in inflammatory diseases of the bowel. Gastroenterology 1982; 82: 673-9.

141 Parks DA, Bulkley GB, Granger DN, Hamilton SR, McCord JM. Ischaemic injury in 
the cat small intestine: role of superoxide radicals. Gastroenterology 1982; 82: 9-15.

142 Webel ML, Ritts RE, Taswell HF. Donadio JV. Woods JE. Cellular immunitiy after intravenous administration of methyl prednisolone. J Lab Clin Med 1974; 83: 383-92.

143 Tanner AR. Halliday JW. Powell LW. Effect of long-term corticosteroid therapy on monocyte chemotaxis in man. Scan J Immunol 1980) 11: 335-40.

144 Rhodes JM, Jewell DP. Inhibition of leucocyte motility by drugs used in inflammatory bowel disease. Gut 1981: 22: 642-7.

145 Werb Z. Biochemical actions of glucocorticoids on macrophages in culture. Specific inhibition of elastase. collagenase and plasminogen activation secretion and effects on other metabolic functions. $J$ Exp Med 1978; 147: 1695-712.

146 Gassmann AE, van Furth R. The effect of azathioprine on the kenetics of monocytes and macrophages during the normal steady state and an acute inflammatory reaction. Blood 1975; 46: 51-64.

147 van Furth R. Gassmann AE. Dieselhoff-Den Dulk MMC, Martina MC. The effect of azathioprine (Imuran) on the cell cycle of pro-monocytes and the production of monocytes in the bone marrow. J Exp Med 1975; 141: 531-46.

148 Smith PR. Dawson DJ. Swan CHJ. Prostaglandin synthetase activity in auute ulcerative colitis: effects of treatment with sulphasalazine, codeine phosphate and prednisolone. Gut 1978; 20: 802-5.

149 Sharon P, Ligumsky M, Rachmilewitz D. Zor U. Role of prostaglandins in ulcerative colitis. Enhanced production during active disease and inhibition by sulfasalazine. Gastroenterology 1978; 75: 638-40.

150) Golder JP. Doe WF. Isolation and preliminary characterisation of human intestinal macrophages. Gastroenterology 1983; 84: 795-8(2).

151 Sherlock S. Patterns of hepatocyte injury in man. Lancet 1982; 1: 782-6.

152 Meuret G, Hoffmann G. Monocyte kinetic studies in normal and disease states. $\mathrm{Br} J$ Haematol 1973; 24: 275-85.

153 Diesselhoff-den Dulk MMC. Crofton RW, van Furth R. Origin and kinetics of Kupffer cells during an acute inflammatory response. Immunology 1979; 37: 7-14.

154 Kinsky RG, Christie GH. Elson J, Howard JG. Extrahepatic derivation of Kupffer cells during oestrogenic stimulation of parabiosed rats. Br J Exp Pathol 1969; 50: 438-47.

155 Holdstock G, Leslie B, Hill S, Tanner AR. Wright R. Monocyte function in cirrhosis. J Clin Pathol 1982; 35: 972-9.

156 DeMeo AN. Anderson BR. Defective chemotaxis associated with serum inhibitor in cirrhotic patients. $N$ Engl J Med 1972; 286: 735-40.

157 Von Epps DE, Strickland RG. Williams RC. Inhibitors of leukocyte chemotaxis in alcoholic liver disease. Am J Med 1975; 59: 200-7.

158 Hassner A. Kletter Y, Shlag D, Yeduab M, Aronson M, Shibolet S. Impaired monocyte function in liver cirrhosis. $\mathrm{Br}$ Med $J$ 1981; 282: 1262-3.

159 Pagliaro L. Giglio F, LeMoli S, Catania A. Citarella P. $\beta$ glyucuronidase and acid phosphatase activities of lysosomal preparations from human liver tissue obtained by needle biopsy from subjects with acute hepatitis and cirrhosis. J Lab Clin Med 1964; 63: 977-85.

160 Pineda EP, Goldbarg JA. Banks BM. Rutenberg AM. The significance of serum $\beta$ glucuronidase activity in patients with liver disease. Gastroenterology 1959; 36: 202-13.

161 Hirata K. Kaneko A. Oganawa K. Hagasaka H. Onoe T. Effect of endotoxin on rat liver. Analysis of acid phosphatase isozymes in the liver of normal and endotoxin-treated rats. Lab Invest 1980; 43: 165-71.

162 Tanner AR, Keyhani AH, Wright R. The influence of endotoxin in vitro on hepatic macrophage lysosomal enzyme release in different rat models of hepatic injury. Liver 1983; 3: 151-60.

163 Saito K, Suter E. Lysosomal acid hydrolases in mice infected with BCG. J Exp Med 1965; 121: $727-38$.

164 Tanner A, Keyhani AH, Arthur M. Wright R. Evidence for a sequence of macrophage activation during recruitment into the liver. In: Knook DL, Wisse E, eds. Sinusoidal liver cells. Amsterdam: Elsevier, 1982: 405-12.

165 Williams GM, Bermudez E, San RHC, Goldblatt PJ, Laspia MF. Rat hepatocyte primary cultures. IV. Maintenance in defined medium and the role of production of plasminogen activator and other proteases. In Vitro 1978; 14: 824-37.

166 Cox DW, Smyth S. Risk for liver disease in adults with alpha, ${ }_{1}$-antitrypsin deficiency. Am J Med 1983; 74: 221-7.

167 Datta DV, Jones WA, Isselbacher $\mathrm{KJ}$. Lysosomal injury in murine viral hepatitis. 
(jastroenterology 1967; 52: 828-36.

168 Allison AC, Sandelin K. Activation of lysosomal enzymes in virus infected cells and its possible relationship to cytopathic effects. J Exp Med 1963; 117: 879-87.

169 Deimann W, Fahimi HD. Hepatic granulomas induced by glucan. An ultrastructural and peroxidase cytochemical study. Lab Invest 198(); 43: 172-81.

170) Holdstock G, St J Hammond PG, Iles S, Smith JL, Tanner AR, Wright R. Activation of monocytes by portal serum and its relationship to immunoglobulin, immune complex and endotoxin content. Liver 1982; 2: 222-9.

171 Souhami RL, Bradfield JWB. The recovery of hepatic phagocytosis after blockade of Kupffer cells. J Reticuloendothel Soc 1974; 16: 75-86.

172 Blackwell JB. Cirrhosis resulting from repeated injections of antigen. J Path Bact 1965; 90: 245-57.

173 Fisher ER, Fisher B. Hepatic damage by reticuloendothelial interference. Arch Pathol 1963; 75: 191-5.

174 Wardle N, Anderson A, James O. Kupffer cell phagocytosis in relation to BSP clearance in liver and inflammatory bowel diseases. Dig Dis Sci 1980); 25: 414-9.

175 Saba TM. Physiology and physiopathology of the reticuloendothelial system. Arch Intern Med 1970; 126: 1031-52.

176 Liehr H, Grun M. Clinical aspects of Kupffer cell failure in liver diseases. In: Wisse E, Knook DL, eds. Kupffer cells and other liver sinusoidal cells. Amsterdam: Elsevier, 1977: 427-36.

177 Fulenwider JT, Sibley C, Stein SF, Evatt B, Nordlinger BM, Ivey GL. Endotoxaemia of cirrhosis: an observation not substantiated. Gastroenterology 1980; 78: 10(01-4.

178 Prytz H, Holst-Christensen J, Korner B, Liehr H. Portal venous and systemic endotoxaemia in patients without liver disease and systemic endotoxaemia in patients with cirrhosis. Scand J Gastroenterol 1976; 11: 857-63.

179 Janoff A, Weissmann G, Zweifach BW, Thomas L. Pathogenesis of experimental shock IV. Studies on lysosomes in normal and tolerant animals subjected to lethal trauma and endotoxaemia. J Exp Med 1962; 116: 451-66.

180) Rogoff TM, Lipsky PE. Role of Kupffer cells in local and systemic immune responses. Gastroenterology 1981; 80: 854-60.

181 Colman JC, Morgan MY, Scheuer PJ, Sherlock S. Treatment of alcohol-related liver disease with (+)-cyanidanol-3; a randomised double blind trial. Gut 1980; 21: 965-9.

182 Hogg N. Human monocytes are associated with the formation of fibrin. $J$ Exp Med 1983; 157: 473-85.

183 Kurkinen M, Vaheri A, Roberts PJ, Stenman S. Sequential appearance of fibronectin and collagen in experimental granulation tissue. Lab Invest 1980; 43: 47-51.

184 Voss B, Rauterberg J, Brehmer U, Pott G. Investigations on the biosynthesis of connective tissue components by cultured mouse liver macrophages and mouse peritoneal macrophages and mouse peritoneal macrophages. In: Knook DL, Wisse E, eds. Sinusoidal liver cells. Amsterdam: Elsevier, 1982: 201-8.

185 McIver CA, Cooksley WGE, Grotendorst GR, Jones EA. Synthesis of chemoattractants for smooth muscle cells by Kupffer cells monocytes - potential implications for hepatic fibrogenesis. [Abstract] Hepatology 1982; 2: 725A.

186 Popper H. Summary of symposium. In: Wisse E, Knook DL, eds. Kupffer cells and other liver sinusoidal cells. Amsterdam: Elsevier, 1977: 509-14.

187 Kent G, Gray S, Inouge T, Babu R, Minick OT, Popper H. Vitamin A-containing lipocytes and formation of Type III collagen in liver injury. Proc Natl Acad Sci USA 1976; 73: 3719-22. 